\title{
ALTERNARIA BLIGHT OF BACHELOR'S BUTTON (GOMPHRENA GLOBOSA L.)
}

\author{
By L. A. ALVAREZ GARCIA \\ Phytopathologist, Agricultural Experiment Station, Rio Piedras, Puerto Rico
}

During the hot, humid summer of 1937, the writer observed a severe case of leaf and stem blight of the ornamental plant commonly known as Bachelor's Button (Gomphrena globosa L.), in flower gardens in the neighborhood of Río Piedras. Outbreaks of the blight were later observed throughout the Island. In every instance an Alternaria species was isolated from affected leaf and stem tissues of diseased plants collected in flower gardens. A similar fungus was also isolated from the wild species $G$. dispersa Standley. Pathogenicity test with these fungi showed that - both organisms were one and the same species. The purple, white and red varieties of $G$. globosa were found to be equally susceptible to the disease.

top to the present and to the author's knowledge, there has never been reported in Puerto Rico a fungus of the genus Alternaria attacking Gomphrena species. Apparently there is no record of such occurrence in American literature.

In Japan, Togashii (1) reported a severe blight of G. globosa and showed by artificial inoculation with conidia of an Alternaria species, that this fungus was the causal agent of the disease. No infection, however, was obtained when inoculating with conidia obtained from pure cultures of the fungus. Yoshii (2) also reported a similar organism, resembling morphologically A. gomphrenae Togashii responsible for a leaf spot of G. globosa. The organism however, is claimed to be different to that previously reported by Togashii as far as cultural characters are concerned. Both species of Alternaria produced similar clinical syndroms, characterized by dark reddish purple spots with smoky-gray necrotic centers.

The leaf symptoms of the Alternaria blight observed in Puerto Rico correspond with those described in Japan. The morphology and physiology of the Alternaria species prevalent in Puerto Rico seems to justify our assumption that this fungus is the same species already reported and described in Japan by Togashii.

\section{THE DISEASE}

The first noticeable symptoms of the disease under our environmental conditions were the appearance of small $(0.25-0.50 \mathrm{~mm}$. in diameter) yellowish-green spots, visible on both sides of the leaves, although more conspicuously on the upper side. These spots were produced more rapidly 
and abundantly on the lower leaves. As the spots enlarged and grew older, they turned yellowish-brown, forming concentric rings of varying shades of that color. The innermost necrotic tissues became discolored and translucent. The invaded tissues around the yellowish-green spots turned first dull green and with the advance of the disease became discolored. When the lesions seemed to have finished their enlargement, a reddish halo was formed encircling the yellowish-brown spot. This halo was characteristic of the disease and did not fade out except when the lesions were very old and the leaf had turned light brown. In some spots, for some reason, the halo was not formed or was very pale. In old lesions although the halo had vanished, the affected necrotic areas were sharply defined. The spots appeared scattered all over the leaf surfaces and were of a subcircular outline, except when they occurred near the margins or near the veins, in which case they became irregular. Nearby spots enlarged, coalesced, and envolved a great part of the leaf. With the progress of the disease, the leaves corrugated and rolled, becoming finally dirty brown throughout and were found hanging down along the stems. They stayed in this position for several days and then dropped. The lesions on the stems were very similar to those found on the leaves. However, on the stems they were elongated. Some of the stem lesions on becoming old lost their dahlia-carmine halo and a whitish discolored area remained. These lesions enlarged, coalesced and girdled the plant.

THE PATHOGENE

Methods of isolation. During the summer of 1937, the fungus was isolated from fresh, young lesions on leaves and stems of the purple variety of G. globosa L., by planting pieces of diseased tissues, previously disinfected for 2-3 minutes in a 1-1,000 solution of bichloride of mercury and afterwards washed several times in sterilized water, on agar plates and from dilution plates of conidia washed from young lesions.

The organism in culture. The fungus grew well in potato-dextrose agar, prune agar, bean agar, Cook's No. 2 agar, and oatmeal agar. In oatmeal agar, the organism formed aerial, cottony, white to light gray mycelium and olive-brown or ochreous trophic and fructiferous growth. The nonfertile hyphae were elongate-septate, minutely guttulate and with septa spaced from 25 to $83 \mu$ and slightly constricted. Fertile hyphae were recognized by the toruloideous sub-fasciculate shape, by the presence of. large, refractive oil globules which in some instances filled the lumen of the cell and by the closeness of the septa, spaced from 3.6 to $7.2 \mu$. These fertile hyphae were definitely light brown or ochreous in color, and were found to produce numerous chlamydospore like bodies. The substratum of the media and particularly those with a high content of carbohydrates 
was tinged dark brown or ochreous. Sporulation occurred on oatmeal agar and in small amount. The conidiophores as well as the conidia were formed from protuberances of the cells and were hyaline at first. Later, at maturity, they turned light-brown or ochreous. No sporulation took place in other culture media.

Morphology on the host. The fungus once it had entered the host, ramified and spread in the host tissues. The hyaline hypha, of approximately $8 \mu$ in thickness, was septate and slightly constricted at the septa. Eventually, the invaded tissues were killed, became necrotic, and of a yellowishbrown color. The conidiophores were produced amphigenously, although more abundantly on the upper side of the leaf, and particularly along the yellowish-brown area next to the dahlia-carmine halo. These conidiophores were produced singly or in thin tufts, erect or subdecumbent; were 1 to 5 septate and from 35 to 70 by 4 to $5 \mu$ in width and emerged by way of the stomata or pushed their way through the necrotic areas of the lesions. The conidia, formed generally singly at the apex of the conidiophores, were easily detached, being elongate, obclavate, with basal and blunt or pointed, 1 to 9 septate, and slightly constricted at the septa; longitudinal septa few or lacking, granular or with refractive oil globules, 60 to 160 by 12 to $16 \mu$, long beaked, never branched, septated every 10 to $15 \mu$ and ranged from one to three times the length of the broadest part of the spore.

\section{PATHOGENICITY}

Plants grown from seeds in sterilized soil were inoculated on August 8, 1937 in the afternoon of a cloudy day with a suspension of spores washed from the typical lesions and from pure culture, respectively. Two sets of plants were inoculated by means of a DeVries atomizer. No lesions were made to the leaves, stems or branches. Half of the plants from each group were covered with bell jars and the others were left uncovered. Control plants were similarly treated but not inoculated. Three days later, typical tiny yellowish green, spots were evident. Microscopic examination of the matured lesions showed the constant association of the pathogene. Reisolations from the newly formed lesions ratified the pathogenicity of the organism. Conidia were found to be produced within 4 to 6 days after inoculation.

\section{EPIPHYTOLOGY}

High temperature combined with ample atmospheric moisture seemed to favor the development of the parasite. Under such environmental conditions spores were produced abundantly on leaf lesions. Spores are spattered by rain drops or carried by wind. New cases of Alternaria blight appeared on plants where the spores have landed. Saprogenesis appeared to occur in debris of diseased plants. 
CONTROL

Eradication of dead or severely diseases plants, as well as the destruction of all diseased material by deep plowing or by burning, clean cultivation, good drainage and planting during the dry season will contribute in checking the disease.

\section{SUMMARY}

1. An Alternaria sp. is reported occurring on Gomphrena globosa L. and $G$. dispersa Standley.

2. All the ornamental varieties as well as the wild type are susceptible to the disease.

3. The disease is recognized by the sub-circular, yellowish-brown lesions on stems and leaves with a characteristic reddish halo.

4. The pathogene, an Alternaria sp. is described.

5. Conidia from young lesions as well as from an oatmeal culture were used for morphological, physiological and inocuiation purposes.

6 . The inoculation tests with spore suspensions taken respectively from young lesions as well as from culture proved the pathogenicity of the organism.

7. Conidia placed in water and at room temperature (28 C.) started germination within an interval of 2 to 3 hours.

8. Sporulation was noticed on lesions on the leaves and never on the stems. Dead parts of the plants seem to harbor the pathogene.

9. The disease is more severe during hot, rainy weather.

RESUMEN EN ESPAÑOL

Durante el verano de 1937, especialmente en la-vecindad de Río Piedras, se pudo observar la difusión de una enfermedad atacando las hojas y las ramas de las siemprevivas (Gomphrena globosa L. y G. dispersa Standley). Se presenta esta enfermedad en las hojas inicialmente con manchas esparcidas, rara vez confluentes, pequeñas de 0.25 a $0.50 \mathrm{~mm}$. de diámetro, circulares, amarillentas y bordeadas por una zona verde mate. Las lesiones al aumentar de tamaño pueden ser irregulares, confluentes y presentan los tejidos centrales necróticos y de color pardo claro y rodeados muy claramente por un área de color rojizo, persistente. Las hojas atacadas se deforman, mueren, cayéndose finalmente. En los' tallos las lesiones muestran características similares, pero son generalmente irregulares, alargadas y unilaterales, pero en ciertas ocasiones son confluentes, rodeando el tallo y produciendo la muerte de la parte superior.

Un examen microscópico de las lesiones muestra los tejidos serpenteados por el micelio tabicado de un hongo de donde emergen, sea a través de los 
tejidos o por estomas, los hacecillos de conidioforos simples, obscuros, contínuos o tabicados, al extremo de los cuales se forman esporas mazudas, oliváceas y acres, tabicadas longitudinal y transversalmente, lo que cataloga a este organismo patógeno entre los hongos del género Alternaria. Siendo esta especie un nuevo record para Puerto Rico, se describe a continuación:

Alternaria gomphrenae Togashii. En nuestro ambiente este hongo produce conidióforos obscuros, tabicados una o cinco veces transversalmente, solitarios o fasciculados, erguidos o inclinados, simples o ramosos. Los conidios oliváceos u ocres, mazudos, con el ápice extremadamente alargado y fino, con 1 ó 9 tabiques transversales y con o ningún tabique longitudinal; el contenido granular u oleaginoso, de 60 a 160 por 12 a $16 \mu$. en tamaño.

- La enfermedad se nanifiesta mayormente en épocas de lluvias frecuentes y en sitios donde hay poca aereación y mal avenamiento.

\section{REFERENCES}

(1) Togashii, K., On a new species of Alternaria causing a leafspot of Gomphrena - globosa L. Bull. Imper. Coll. Agric. \& Forestry (Marioka, Japan) IX, pp. 1-16, 4 figs. 1926. (Abstract in Rev. Appl. Myc., 5, 671, 1926).

(2) Yoshii, H., On the pathogenic organism of the leaf spot of Gomphrena globosa L. Am. Phytopath. Soc., Japan ii, 6, pp. 513-519, 1 fig. 1933. (Abstract in Rev. Appl. Myc., 13, 31, 1934.) 